\title{
A Study on the Effectiveness of Spiritual Intervention on Perception of God and Attitude toward Death in Women with Breast Cancer
}

Saeedeh Sarafraz Mehr

Narjes Saberian

Mohammad Esmaeil Akbari

Fatemeh Modarresi Asem

Cancer Research Center, Shahid Beheshti University of Medical Sciences, Tehran, Iran

\begin{abstract}
Desperation, death threat, recurrence of disease, anxiety about the future, suffering from pain, personal, family and social problems arising from bad performance has made it necessary to pay attention to this important disease. Using spiritual intervention has an important role in reducing mental complications and promoting the patients' health. This study was a quasiexperimental with pre-test and post-test, and control group. The statistical population included women with breast cancer referred to the Cancer Research Center of Shohada Hospital in 2015 that 24 people were selected by available method and were divided into two groups randoml. The experimental group was exposed to spiritual intervention and the control group was not exposed to any intervention. For measuring research variables, 72 items of God's perception and 32 items of attitude toward death (DAPR) questionnaires were used and the covariance analysis was used for analyzing data. The results of the research showed that using spiritual intervention $(\mathrm{P}<0.05)$ in-group was effective significantly in improving perception of God and reducing the fear and avoidance of death in the women's group with breast cancer. Reminding this attachment, sense between the creator and creature creates a good relationship between patient and God. The death anxiety will reduce with the help of focusing on the kindness and forgiveness and attempts to the good acts in this universe and the reality of the human survival in another universe, which is a movement from the potential perfection to the active perfection.
\end{abstract}

Keywords: spiritual intervention, perception of god, attitude toward death, breast cancer 


\section{Introduction}

The attention of the different psychological schools to the human and his needs and spiritual studies in this level is an important and fundamental matter and it is increasing in many countries. Meaning as an introduction for discussing about spirituality, connects with the internal aspects of human and spirituality contains the self-perceptions and combination of characteristic factors and fundamental beliefs about the being and having a meaning in life which relates to the aspect and spirituality of different life relations such as social, physical and psychological aspects (Yang \& Mao, 2007). The fundamental research has found the positive relations between increasing the spirituality and health results, about the relationship between the spirituality and health (Peach, 2003). Many research showed that spirituality, from a normal prayer to the meditation and attending in religious ceremonies have such an effect on human health from increasing life expectancy, enhancing the immune system, improving the body's response to stress, recovering from depression and helping the patients to recover from severe illnesses such as cancer, cardiovascular disease and other diseases that science is incapable in proving it (Paloutzian \& Park, 2014; Yang \& Mao, 2007). Some cancer patients have concluded that spirituality can increase resistance against the physical and psychological crises that are followed by the diagnosis and treatment of these diseases. In addition, it has been observed in women with breast cancer that encouraging toward spirituality could be as an effective source to deal with physical and psychological responses to cancer (Meraviglia, 2004).

Spirituality sets a goal in an individual's beliefs and affects important cognitive assessments in the process of confrontation, and helps the person to assess the negative events in a different way and create a stronger sense of control (Simoni, Martone, \& Kerwin, 2002). As the human ability in controlling stressful events will increase, his ability to adapt to the environment will be more and stress-induced sideeffects such as anxiety and depression will appear less (Seligman, 1974). Human nature is spiritual and religious. Until this spiritual dimension of a person does not connect to a person's psychological structure and does not integrate with it, his real treatment does not happen (Jung, 2014). Spiritual and religious beliefs provide hope and a sense of control over one's destiny and if the believer has a complete trust in God, he could obtain a good result in any condition and it is not surprising that such a belief may have a powerful psychological outcome. Human in health and disease, is like a unit with different aspects of biological, psychological, social and spiritual. Thus, it is appropriate to avoid a one-dimensional encounter in the treatment. Given that, social, psychological, and spiritual factors are directly associated with a patient's beliefs and culture, so to recover from disorders and diseases, these beliefs and resources are used. New research with statistical considerations are growing up in finding the beneficial effects of spirituality and religion. 
So religious and spiritual beliefs and new scientific advances can be used together in the treatment of disorders and diseases (Riley et al., 1998). Among the diseases and the accidents, cancer is known as one of the most important causes of death in the world that is estimated by 2020; more than 15 million people worldwide will experience it (Daher, 2011). In Iran, the third largest cause of death is influenced by genetics and environment. The occurrence of this disease is reported in adult age groups and in different regions of Iran, 48-112 cases per hundred thousand people for females and 51-144 cases per hundred thousand for men (Seyedfatemi, Borimnejad, Hamooleh, \& Tahmasebi, 2014). In this regard, it is predicted in 2030, due to the increasing average age of the population, relative control of communicable diseases and increased carcinogenic factors, cancer will be the most important and the first factor of death in human (Mohaghegh \& Hamta, 2008). This disease is a manifestation of chronic injury (Henson, 2002) that causes physical and emotional symptoms and has negative effects on people's quality of life (Borimnejad, Hamooleh, Seyedfatemi, \& Tahmasebi, 2014). Among them, the breast cancer is the most common cancer among women (Forouzanfar et al., 2011). In 2010, 16 million women in the world were diagnosed with breast cancer and 425 thousand people have lost their lives due to this cancer (Henson, 2002) and by its increasing growth of 32.2 per hundred thousand people, it has become the most common malignancies in Iran among women (Yavari, Mosavizadeh, Sadrol-Hefazi, \& Mehrabi, 2005). Age incidence of breast cancer in Iran is 41 to 60 years, and statistics show that $34.3 \%$ of all cases is occurred less than 40 years (Sirus \& Ebrahimi, 2009). The disease, like all chronic diseases, is including the changing risks and problems that over time often find intensity. Distress and suffering caused by this disease are more focused on the threat, death, recurrence, and the concern about the future and the suffering caused by pain (Petro-Nustas, 2002). Therefore, it seems necessary to manage more than ever the symptoms of disease and to improve quality of life for cancer patients as well.

\section{Research Method}

This study was a quasi-experimental with pre-test and post-test, and a control group and its statistical population include women with breast cancer referred to the Cancer Research Center, Shahid Beheshti University of Medical Sciences, in 2015. In this population, 24 patients were selected with available sampling method and divided randomly into two groups included 12 people in the control group and 12 people in the experimental group. Inclusion criteria in the study were:

1. Having a minimum reading and writing ability.

2. Stage one and two in breast cancer.

3. Completion of treatment (surgery, chemotherapy, radiotherapy, hormone therapy) from six months to one year.

4. Not having the same clinical disorder. 
5. Not receiving any psychological or medication treatment from the six months prior to the intervention time and during spiritual intervention.

Exclusion criteria for the study included:

1. Significant Clinical impairment after the interview.

2. Patient's refusal from participating in the group for any reason.

Participants receive complete details of this study and its objectives and gave their consent, and have entered the study, and then the experimental group has received spiritual intervention in 10 sessions of 90 minutes. The control group did not receive any intervention. Groups were tested before and after intervention, by God Perception and Attitude toward death questionnaires.

Components of spiritual intervention were performed by using of the funds of Quranic and Islamic and international standards. They have all emphasized the peace and human growth and development and the acceptance of God as the power of the kind, which leads to confidence and reduce anxiety and stress inhibition. This intervention was performed during 10 sessions, once a week and each time was for 90 minutes. The framework of the each therapy session, as an example, is following as Table 1:

Table 1. Framework of the Each Therapy Session

\begin{tabular}{|l|l|}
\hline Row & Detail of Therapy \\
\hline 1 & $\begin{array}{l}\text { Prayer beginning of the session, with the aim of reminding } \\
\text { attended in the spiritual and emotional meeting and closeness to } \\
\text { the Lord }\end{array}$ \\
\hline 2 & Literature review and revise the homework session \\
\hline 3 & $\begin{array}{l}\text { Clarification of this meeting subject with the participation of the } \\
\text { members }\end{array}$ \\
\hline 4 & $\begin{array}{l}\text { Session topics discussed by member use the components of the } \\
\text { spiritual-religious and Islamic }\end{array}$ \\
\hline 5 & Summaries \\
\hline 6 & Homework \\
\hline 7 & End of session with prayer \\
\hline 8 & Individual and specific guidance \\
\hline 9 & Publishing an overview of the issues \\
\hline
\end{tabular}

The content of the meetings in 10 sessions is as following:

- Session One: Introduction and preparations. A) Introduction of the members with each other, awareness of the reasons for forming the groups, B) reminding Challenge (personal and implications awareness of spirituality and its definition from the perspective of each member, considering the presence 
of the belief in the superior force and calls on Member and client perceptions and beliefs about spirituality).

- Session Two: introspection and descriptions. Focus on inner feelings and identifying them in the time that they had spiritual experiences.

- Session Three: Sources of fear and anxiety and our resources against them. Trying to find out what causes fear and anxiety in patients' lives and partnership to address and resolve them.

- Session Four: inexhaustibility and inheritance. Defining the inexhaustibility and unfailing. Try to inexhaustible. Heritage in our life and the impact on the others.

- Session Five: Inherited on love or hate. The definition of love and hate and that is which one brings us peace? How to bring love and consider the results and what affects this love or hate bring to others?

- Session Six: meditation. Addressing the effects of behaviors based on love or hate on ours and others and the world. Trying to keep our behaviors based on love and keep away from hate.

- Session Seven: patience. Addressing the world and its hardships. Human explains to suffer and emphasizes the waiting for the problems that is necessary for life. Provide experience based on waiting and its implications for patients. Compare the experience of waiting with no waiting.

- Session Eight: forgiveness and resolve anger. Focus on forgiveness and resolve anger toward self, others and the world and trying to revive behaviors based on acceptance, patience, persistence, responsible action and social and personal benefits.

- Session Nine: trust, to discuss and provide comments about who is better to trust than the God is since he knows better than we know and rules the world. He knows our favor and universe is ruled by his wisdom. Addressing the effort combined with trust. Assigning the whole life affairs to the God. Offering the experiences of trust, this is what happened then? Was there a peace?

- Session Ten: calculating, meditation and sustainability. Discuss the increasing self-control to maintain awareness in behaviors based on love and virtuous and avoiding behaviors based on hate and malicious. Trust on what leads to personal and community benefit (Akbari M, Vaziri S, \& Lotfi Kashani, 2016).

The God Greeley perception test is a test of 72 items that has six sub-scales of the existence, challenge, acceptance, compassion, impact and Providence, and runs as a Likert. For normalization, 455 students were selected from the University of Ferdowsi in Mashhad, Iran. The reliability of the test was in: 
- The scale of the existence: 0.94

- Challenge: 0.86

- Acceptance: 0.90

- Compassion: 0.91

- Impact: 0.92

- Providence: 0.92

- Total reliability: 0.91

Additionally, in order to determine the validity criterion, another validated questionnaire with 27 questions called the image of God test has been used that had the alpha coefficient equal to 0.89 . Based on 158 raw scores (number of classes) that have obtained in two samples, the "Z" normative scores and "T" normative scores have been reported that the highest score achieved was 288. The minimum score obtained in the experimental implementation of the " $Z$ " is (-24.2) and score " $T$ " is obtained (6.27).

Wing \& Rucker and Geser in 1994 developed the revised profile view of death in 1994. The scale has 32 words and five dimensions and its measures fear of death, avoidance of death, neutral acceptance, acceptance of tendency and avoidance acceptance. The subjects are identified in a Likert scale of seven degrees. They have reported the retest to avoid death as (0.61), fear of death (0.71), neutral acceptance (0.64), and acceptance of tendency (0.95), and avoidance acceptance (0.83). Sub-scale of fear of death has a positive correlation with death anxiety scale. The sub-scale of admission trend and neural acceptance and avoidance acceptance have a positive correlation with Attitude Scale of death. The existence of such a relationship reflects the desirable structural validity of five sub-scale of the test. To compare the scores of God perception and attitude towards death to test and control groups, the covariance analysis was used and data were analyzed with SPSS software by version 21 .

\section{Analysis Result}

The study descriptive scales in Table 2 are provided in pre-test and post-test in experimental and control groups. As can be seen in the perception of God scale, the average of the experimental group in the post-test stage shows an increase compared to pre-test. According to the results in Table 2, it can be described as spiritual therapy has resulted in a significant increase in positive perception of God. Also, among the sub-scales of attitudes toward death in the experimental group, avoidance of death and fear of death is declined and somewhat trend acceptance and the neutral acceptance are increased.

Table 2. Descriptive Information of Variable Scores on the Breakdown of the Measured Stage in Groups 


\begin{tabular}{|c|c|c|c|c|c|}
\hline Variable & \multicolumn{2}{|l|}{ Group } & Numbers & Mean & $\begin{array}{l}\text { Standard } \\
\text { Deviation }\end{array}$ \\
\hline \multirow{4}{*}{$\begin{array}{l}\text { Perception } \\
\text { of God }\end{array}$} & \multirow{2}{*}{ Experiment } & $\begin{array}{l}\text { Pre- } \\
\text { test }\end{array}$ & 12 & 175.33 & 16.04 \\
\hline & & $\begin{array}{l}\text { Post- } \\
\text { test }\end{array}$ & 12 & 198.08 & 16.11 \\
\hline & \multirow{2}{*}{ Control } & $\begin{array}{l}\text { Pre- } \\
\text { test }\end{array}$ & 12 & 168.58 & 26.56 \\
\hline & & $\begin{array}{l}\text { Post- } \\
\text { test }\end{array}$ & 12 & 170.91 & 28.09 \\
\hline \multicolumn{6}{|c|}{ Attitude toward Death } \\
\hline \multirow{4}{*}{$\begin{array}{l}\text { Fear of } \\
\text { Death }\end{array}$} & \multirow{2}{*}{ Experiment } & $\begin{array}{l}\text { Pre- } \\
\text { test }\end{array}$ & 12 & 5.15 & 1.84 \\
\hline & & $\begin{array}{l}\text { Post- } \\
\text { test }\end{array}$ & 12 & 4.36 & 1.22 \\
\hline & \multirow{2}{*}{ Control } & $\begin{array}{l}\text { Pre- } \\
\text { test }\end{array}$ & 12 & 3.95 & 1.88 \\
\hline & & $\begin{array}{l}\text { Post- } \\
\text { test }\end{array}$ & 12 & 3.96 & 1.86 \\
\hline \multirow{4}{*}{$\begin{array}{l}\text { Death } \\
\text { Avoidance }\end{array}$} & \multirow{2}{*}{ Experiment } & $\begin{array}{l}\text { Pre- } \\
\text { test }\end{array}$ & 12 & 5.49 & 0.94 \\
\hline & & $\begin{array}{l}\text { Post- } \\
\text { test }\end{array}$ & 12 & 4.49 & 1.22 \\
\hline & \multirow{2}{*}{ Control } & $\begin{array}{l}\text { Pre- } \\
\text { test }\end{array}$ & 12 & 3.78 & 1.69 \\
\hline & & $\begin{array}{l}\text { Post- } \\
\text { test }\end{array}$ & 12 & 3.75 & 1. 68 \\
\hline \multirow{4}{*}{$\begin{array}{l}\text { Neutral } \\
\text { Acceptance }\end{array}$} & \multirow{2}{*}{ Experiment } & $\begin{array}{l}\text { Pre- } \\
\text { test }\end{array}$ & 12 & 5.10 & 1.09 \\
\hline & & $\begin{array}{l}\text { Post- } \\
\text { test }\end{array}$ & 12 & 5.55 & 1.87 \\
\hline & \multirow{2}{*}{ Control } & $\begin{array}{l}\text { Pre- } \\
\text { test }\end{array}$ & 12 & 4.76 & 1.74 \\
\hline & & $\begin{array}{l}\text { Post- } \\
\text { test }\end{array}$ & 12 & 4.61 & 0.81 \\
\hline \multirow{3}{*}{$\begin{array}{l}\text { Tendency } \\
\text { Acceptance }\end{array}$} & \multirow{2}{*}{ Experiment } & $\begin{array}{l}\text { Pre- } \\
\text { test }\end{array}$ & 12 & 5.2 & 0.95 \\
\hline & & $\begin{array}{l}\text { Post- } \\
\text { test }\end{array}$ & 12 & 5.61 & 1.70 \\
\hline & Control & $\begin{array}{l}\text { Pre- } \\
\text { test }\end{array}$ & 12 & 5.45 & 1.71 \\
\hline
\end{tabular}




\begin{tabular}{|l|l|l|l|l|l|}
\hline & & $\begin{array}{l}\text { Post- } \\
\text { test }\end{array}$ & 12 & 5.23 & 0.81 \\
\hline & Experiment & $\begin{array}{l}\text { Pre- } \\
\text { test }\end{array}$ & 12 & 4.39 & 1.86 \\
\cline { 2 - 6 } $\begin{array}{l}\text { Avoidance } \\
\text { Acceptance }\end{array}$ & $\begin{array}{l}\text { Post- } \\
\text { test }\end{array}$ & 12 & 4.42 & 0.95 \\
\cline { 2 - 6 } & Control & $\begin{array}{l}\text { Pre- } \\
\text { test }\end{array}$ & 12 & 3.28 & 1.57 \\
\cline { 2 - 6 } & $\begin{array}{l}\text { Post- } \\
\text { test }\end{array}$ & 12 & 3.38 & 1.78 \\
\hline
\end{tabular}

As mentioned earlier in this study, the variables were examined in both experimental and control groups and hypotheses are designed according to the subject that after confirming the assumptions, the multivariate covariance analysis test was used to measure them in Table 3, and Table 4.

Table 3. Tests of Multivariate Covariance Analysis

\begin{tabular}{|c|c|c|c|c|c|c|}
\hline $\begin{array}{l}\text { Statistic } \\
\text { Indicator } \\
\text { Effect }\end{array}$ & Test & Value & $\mathrm{F}$ & $\begin{array}{l}\text { df } \\
\text { Hypothesis }\end{array}$ & $\begin{array}{l}\mathrm{df} \\
\text { Error }\end{array}$ & Sig \\
\hline \multirow{4}{*}{$\begin{array}{l}\text { Differences } \\
\text { Between } \\
\text { Groups }\end{array}$} & $\begin{array}{l}\text { Pillay } \\
\text { Effect }\end{array}$ & 0.71 & 4.43 & 6 & 11 & 0.01 \\
\hline & $\begin{array}{l}\text { Lambda } \\
\text { Wilks }\end{array}$ & 0.29 & 4.43 & 6 & 11 & 0.001 \\
\hline & $\begin{array}{l}\text { Hotelling } \\
\text { Effect }\end{array}$ & 2.42 & 4.43 & 6 & 11 & 0.001 \\
\hline & $\begin{array}{l}\text { The Roi } \\
\text { Largest } \\
\text { Root }\end{array}$ & 2.42 & 4.43 & 6 & 11 & 0.001 \\
\hline
\end{tabular}

Results of Table 3 show that with the multivariate analysis of covariance, there is a significant effect of the factor group. This effect shows a significant difference at least between one of the components of research in the two treatment groups and the control group (Wilks' Lambda $=0.29, \mathrm{p}<0.05$ ).

Table 4. One-Way Analysis of Variance in the Multivariate Analysis of Covariance

\begin{tabular}{|l|l|l|l|l|l|l|l|}
\hline $\begin{array}{l}\text { Statistic } \\
\text { Indicator } \\
\text { Variables }\end{array}$ & $\begin{array}{l}\text { Change } \\
\text { Source }\end{array}$ & SS & df & F & $\begin{array}{l}\text { Significance } \\
\text { Level }\end{array}$ & $\begin{array}{l}\text { Effect } \\
\text { Size }\end{array}$ & $\begin{array}{l}\text { Ability } \\
\text { Test }\end{array}$ \\
\hline $\begin{array}{l}\text { Perception } \\
\text { of God }\end{array}$ & group & 1483.01 & 1 & 17.62 & 0.001 & 0.52 & 0.97 \\
\hline
\end{tabular}




\begin{tabular}{|l|l|l|l|l|l|l|l|}
\hline $\begin{array}{l}\text { Fear of } \\
\text { Death }\end{array}$ & group & 0.81 & 1 & 0.55 & 0.46 & 0.04 & 0.11 \\
\hline $\begin{array}{l}\text { Death } \\
\text { Avoidance }\end{array}$ & group & 0.02 & 1 & 0.02 & 0.89 & 0.001 & 0.05 \\
\hline $\begin{array}{l}\text { Neutral } \\
\text { Acceptance }\end{array}$ & group & 2.32 & 1 & 2.49 & 0.13 & 0.15 & 0.31 \\
\hline $\begin{array}{l}\text { Tendency } \\
\text { Acceptance }\end{array}$ & group & 0.47 & 1 & 0.77 & 0.39 & 0.05 & 0.13 \\
\hline $\begin{array}{l}\text { Avoidance } \\
\text { Acceptance }\end{array}$ & group & 0.04 & 1 & 0.03 & 0.88 & 0.002 & 0.05 \\
\hline
\end{tabular}

As can be seen from the results in Table 4, a significant level of perception of God is smaller than the level obtained from the modified Benferroni significance 0.008 (dividing the significance level of 0.50 on six dependent variables). The effect of the experimental group "Practical Significance" for understanding God was 0.52; it means $52 \%$ of the variance or individual differences intervene in conflicts related to the perception of God in testing group. In addition, high power of statistical tests in this research indicates that the null hypothesis is rejected correctly with a high probability. In addition, none of attitudes to the death sub-scale had a significant change.

\section{Conclusion and Discussion}

This study aimed to determine the effectiveness of the spirituality intervention of God perceptions and attitudes toward death in women with breast cancer. In the long years, various studies have investigated the relationship between religion and spirituality with health (Abu-Ras \& Laird, 2011; Shreve-Neiger \& Edelstein, 2004). In expressing a variety of health-threatening diseases, cancer causes an increase in patients' spiritual needs significantly, and consequently the role of seeking spirituality as an effective source to deal with physical and psychological responses to breast cancer will be considered (Moss \& Dobson, 2006). Spiritual intervention is a religious - cultural process by considering the transcendent dimension of clients, leading to God (Ghobari, Motavalipoor, Hakimirad, \& Habibi, 2009), exploring the issues and spiritual issues and aims at improving the health and recovery (Richards, Hardman, \& Berrett, 2007). Among the considerable amount of studies on the relation between religion and spirituality with health (Abu-Ras \& Laird, 2011; George, Larson, Koenig, \& McCullough, 2000; Shreve-Neiger \& Edelstein, 2004), many of them are considered the effectiveness of spiritual intervention as a source to deal with psychological problems and mental health and quality of life in cancer patients (Breitbart, 2002; Koszycki, Raab, Aldosary, \& Bradwejn, 2010).

Research results showed that spiritual intervention leads to an optimistic attitude toward the perception of God. However, accessing the imaginations of God or the perception of God is difficult (Gattis, 2001). However, this becomes clear different in 
people's own experience that is in contact with the spiritual perception system of them, and at different levels, including search and maintain the presence of God, God is as a safe haven, separation as a source of anxiety and worry and God is like an omnipotent and omniscient (McDonald, Beck, Allison, \& Norswortby, 2005). Now cancer as a disease that in appearance, the person did not involve in creating it directly and has negatively affected the course of his life is effective in the type of relationship between the Lord and patients. Attention of mind in this regard that the cancer was a retribution from the Lord for him changes the perspective of the merciful Lord to the hardship Lord, the God who puts an obstacle on the path of the patient's life to making sickness that inhibits the growth of him. He prays the Lord, but the severity of disease does not decrease and he is suffering from the disease and it seems like he does not hear the patient's voice and the disease happened because of not accurate worshiping him. This kind of thinking is providing anxiety that seems he has been left behind. Some research has shown this type of relationship based on anger in cancer patients (Exline, Prince-Paul, Root, \& Peereboom, 2013).

After a spiritual intervention, suffering from the disease will be changed significantly for patients affected by the disease, now the suffering God, is a God that because of the disease, he seeks a stronger and better communication with his servant. The disease has provided a way for him/her that he/she is thankful and his specific experience has provided new direction of growth for him/her; what is known in psychology as post-traumatic growth and various research confirm what was said (Denney, Aten, \& Leavell, 2011). Not significant waiting has changed to meaningful patience and hope for recovery. His mercy is everlasting and if he does not properly worship him, he believes his generosity. Because of the correction of vision, patients are more properly resolving the problems caused by their disease and improving their quality of life and mental health (Koszycki et al., 2010). On the other hand, the spiritual intervention, focusing on higher behaviors such as forgiving self and others, self-sacrifice, charity and kindness, are focused on improving relationships with other human beings that with improving this relationship, the attitude of a person to self and others will shape that is effective in the way that experiences the God emotionally (Granqvist, Mikulincer, \& Shaver, 2010). Therefore, understanding of God is the psychological structure of the knowledge of mental traits (Lawrence, 1997), it can indicate cognitive development and moral development of the individual and the individual's mental life quality of communication (Alcorn et al., 2010). The dissatisfaction sense of God has a significant relationship with frustration, the feeling and symptoms of depression and guilty feeling (Braam, Mooi, Jonker, Tilburg, \& Deeg, 2008). Instead, people with a positive mental image of God have High psychological coping and evaluate situations positively (Newton \& McIntosh, 2010).

The results of Brady et al. study showed that in patients with cancer, spirituality is associated with the quality of life as the same as the physical health and emotional health (Brady, Peterman, Fitchett, Mo, \& Cella, 1999). Some patients with cancer have considered it as a fight or a divine experiment that was designed by God for their faith, 
while others have considered it as a threat (Taylor, 1983). Thus, the perception of God is as an inner mental functional model that person imagines the God in that way and it can represent growth rate and the psychological maturity level and in a deeper look, it shows the wheel-person's character. God perception is a cognitive-emotional model and a coherent set of the final level of the person's perception in metaphysical matters (Taylor, 1983). With the help of spirituality intervention structure, this growth was obtained from breast cancer patients.

However, the death can be verified as a full stop and no return in the vital functions from the various aspects. Researchers believe that the process of dying is different depending on the type of disease and individual differences in emotional responses (Taylor, 1983) and probably it creates a complex interplay of emotions and swaying thoughts of acceptance and the rejection of the death that tends consistency to one of the parties of acceptance and denial (Taylor, 1983). Different psychological approaches such as existentialism (Henoch \& Danielson, 2009), humanism (Henoch \& Danielson, 2009), Cognitive (Moorey et al., 2009), behaviorism (Redd \& Andrykowski, 1982) and etc., have tried to solve this concept in patients close to death (Redd \& Andrykowski, 1982). Cancer patients are a group of patients that feel more closely with the concept (Lange, Thom, \& Kline, 2008). Hard and painful nature of cancer and increase knowledge of its risk and death and the false beliefs that equal cancer to death are causing the patient fear unrealistically of death (Farsi, Dehghan Nayeri, \& Negarandeh, 2010). Death, due to the ambiguous nature of many human beings, appears as a threat, the fact that people respond in different ways (Farsi et al., 2010). The fear is because of thinking about the process of dying or events that occur after death (Bahrami, Dadfar, Lester, \& Abdel-Khalek, 2014). Fears and emotions related to end of life (Firestone \& Catlett, 2009), that for a patient who is facing it provides more anxiety and affect various aspects of their lives (Firestone \& Catlett, 2009). In spiritual intervention, addressing and promoting the evidence is an inexhaustible and eternal life of man, which is accepting another world thought; it provides the background so that the short life of this world causes less anxiety for them.

Patients knew that suffering is in different forms for all people and the spirituality helped them cope with the nature of death, and endure the pain of life significantly (Tsevat, 2006). Emphasizing the hope of mercy of God and doing righteous and good and trying to leave a good inheritance that realize with helping each other and kindness and many other behaviors, reduces the suffering from the lack of life in this world and is given more constant motivation to live on love. Thus, in numerous studies, hope has a significant positive relation to an increase in compatibility (Farran, Herth, \& Popovich, 1995) and despair has a contrary conclusion (Farran et al., 1995). The fact that in the human history, there is not a human being deprived of facing death causes experiencing less frustration. On the other hand, the disease gave them the opportunity as a favor from the Lord to take care of themselves and their actions and work more and to improve the quality of their lives. So, the attitudes 
toward death test, in subjects with breast cancer had evidence that after spiritual intervention, not only it reduced the sense of avoidance of death, but also with the elimination of irrational fears of the death and life after death that according to Islamic sources, it is such as removing dirty clothes from the body and wear clean clothes, trying to achieve eternal life in the light of Divine Mercy was also tending them. Therefore, in another aspect, the spirituality could reduce the fear of death (Levin, 2000), that it modified the flawed thinking of God and religion that consider the death as entering into a world full of pain (Naderi \& Kh, 2012). Spirituality, especially when the patients are facing death, plays an important role in the physical and mental well-being of them (Aten \& Leach, 2009; Leung, Chiu, \& Chen, 2006).

Because of spirituality brings the relation and integration of human beings beyond the confines of time and space and material and unity in the universe can be seen by spiritual people (GHOBARI et al., 2009) and on this subject, numerous research studies have been done on the effectiveness of spiritual intervention to reduce anxiety and avoid confrontation with death (Al-Sabwah \& Abdel-Khalek, 2006; Wachholtz \& Pargament, 2005). According to what was said, Addressing the spiritual dimension of patients not only should not be neglected, but also it must be addressed more; Where the human tendency to spirituality is increased (Cook, Cook, Powell, \& Sims, 2009) and patients tend to talk to their doctors about their spiritual dimension (Peach, 2003), thus, spiritual approaches are useful interventions in the treatment of clients, by using the language of respect and therapist value toward patient spiritual matters, and in order to use the potential power of faith and spirituality (Richards et al., 2007).

\section{Acknowledgement}

Authors thank the spiritual support of the Cancer Research Center, Shahid Beheshti University of Medical Sciences, Tehran, Iran.

\section{References}

[1] Abu-Ras, W., \& Laird, L. (2011). How Muslim and non-Muslim chaplains serve Muslim patients? Does the interfaith chaplaincy model have room for Muslims' experiences? Journal of Religion and Health, 50(1), 46-61.

[2] Akbari M, Vaziri S, \& Lotfi Kashani, F. (2016). Spirituality Therapy. Cancer Research Center Sahhid Beheshti University of Medical Sciences, Tehran(Iran).

[3] Al-Sabwah, M. N., \& Abdel-Khalek, A. M. (2006). Religiosity and death distress in Arabic college students. Death studies, 30(4), 365-375.

[4] Alcorn, S. R., Balboni, M. J., Prigerson, H. G., Reynolds, A., Phelps, A. C., Wright, A. A., ... Balboni, T. A. (2010). "If God wanted me yesterday, I wouldn't be here today": religious and spiritual themes in patients' experiences of advanced cancer. Journal of palliative medicine, 13(5), 581-588. 
[5] Aten, J. D., \& Leach, M. M. (2009). Spirituality and the therapeutic process: A comprehensive resource from intake to termination: American Psychological Association.

[6] Bahrami, F., Dadfar, M., Lester, D., \& Abdel-Khalek, A. M. (2014). Death distress in Iranian older adults. Advances in Environmental Biology, 56-63.

[7] Borimnejad, L., Hamooleh, M. M., Seyedfatemi, N., \& Tahmasebi, M. (2014). Human relationships in palliative care of cancer patient: lived experiences of Iranian nurses. Materia socio-medica, 26(1), 35.

[8] Braam, A., Mooi, B., Jonker, J. S., Tilburg, W. v., \& Deeg, D. (2008). God image and Five-Factor Model personality characteristics in later life: A study among inhabitants of Sassenheim in The Netherlands. Mental Health, Religion and Culture, 11(6), 547-559.

[9] Brady, M. J., Peterman, A. H., Fitchett, G., Mo, M., \& Cella, D. (1999). A case for including spirituality in quality of life measurement in oncology. PsychoOncology, 8(5), 417-428.

[10] Breitbart, W. (2002). Spirituality and meaning in supportive care: spirituality-and meaning-centered group psychotherapy interventions in advanced cancer. Supportive care in cancer, 10(4), 272-280.

[11] Cook, C., Cook, C. C., Powell, A., \& Sims, A. (2009). Spirituality and psychiatry: RCPsych Publications.

[12] Daher, M. (2011). Opioids for cancer pain in the Middle Eastern countries: a physician point of view. Journal of pediatric hematology/oncology, 33, S23S28.

[13] Denney, R. M., Aten, J. D., \& Leavell, K. (2011). Posttraumatic spiritual growth: A phenomenological study of cancer survivors. Mental Health, Religion \& Culture, 14(4), 371-391.

[14] Exline, J. J., Prince-Paul, M., Root, B. L., \& Peereboom, K. S. (2013). The spiritual struggle of anger toward God: A study with family members of hospice patients. Journal of palliative medicine, 16(4), 369-375.

[15] Farran, C. J., Herth, K. A., \& Popovich, J. M. (1995). Hope and hopelessness: Critical clinical constructs: Sage Publications, Inc.

[16] Farsi, Z., Dehghan Nayeri, N., \& Negarandeh, R. (2010). Coping strategies of adults with leukemia undergoing hematopoietic stem cell transplantation in Iran: a qualitative study. Nursing \& health sciences, 12(4), 485-492.

[17] Firestone, R., \& Catlett, J. (2009). Beyond death anxiety: Achieving lifeaffirming death awareness: Springer Publishing Company. 
[18] Forouzanfar, M. H., Foreman, K. J., Delossantos, A. M., Lozano, R., Lopez, A. D., Murray, C. J., \& Naghavi, M. (2011). Breast and cervical cancer in 187 countries between 1980 and 2010: a systematic analysis. The lancet, 378(9801), 1461-1484.

[19] Gattis, J. P. (2001). Developing a web-based scoring program for the God Image Inventory. Rosemead School of Psychology, Biola University.

[20] George, L. K., Larson, D. B., Koenig, H. G., \& McCullough, M. E. (2000). Spirituality and health: What we know, what we need to know. Journal of social and clinical psychology, 19(1), 102-116.

[21] GHOBARI, B. B., Motavalipoor, A., HAKIMIRAD, E., \& HABIBI, A. M. (2009). Relationship between anxiety and depression and magnitude of spirituality in students of the University of Tehran.

[22] Granqvist, P., Mikulincer, M., \& Shaver, P. R. (2010). Religion as attachment: Normative processes and individual differences. Personality and Social Psychology Review, 14(1), 49-59.

[23] Henoch, I., \& Danielson, E. (2009). Existential concerns among patients with cancer and interventions to meet them: an integrative literature review. Psycho-Oncology, 18(3), 225-236.

[24] Henson, H. K. (2002). Breast cancer and sexuality. Sexuality and disability, 20(4), 261-275.

[25] Jung, C. G. (2014). Psychology and Religion Volume 11: West and East: Routledge.

[26] Koszycki, D., Raab, K., Aldosary, F., \& Bradwejn, J. (2010). A multifaith spiritually based intervention for generalized anxiety disorder: A pilot randomized trial. Journal of clinical psychology, 66(4), 430-441.

[27] Lange, M., Thom, B., \& Kline, N. E. (2008). Assessing nurses' attitudes toward death and caring for dying patients in a comprehensive cancer center. Paper presented at the Oncology nursing forum.

[28] Lawrence, R. T. (1997). Measuring the image of God: The God image inventory and the God image scales. Journal of Psychology and theology, 25(2), 214-226.

[29] Leung, K.-K., Chiu, T.-Y., \& Chen, C.-Y. (2006). The influence of awareness of terminal condition on spiritual well-being in terminal cancer patients. Journal of pain and symptom management, 31(5), 449-456.

[30] Levin, M. (2000). Spiritual intelligence: Awakening the power of your spirituality and intuition: Hodder \& Stoughton. 
[31] McDonald, A., Beck, R., Allison, S., \& Norswortby, L. (2005). Attachment to God and Parents: Testing the Correspondence vs. Compensation Hypotheses. Journal of Psychology \& Christianity, 24(1).

[32] Meraviglia, M. G. (2004). The effects of spirituality on well-being of people with lung cancer. Paper presented at the Oncology nursing forum.

[33] Mohaghegh, F., \& Hamta, A. (2008). Shariat Zade SA Investigation of current cancers in Markazi province and its registration system in 1380-85 in compare with country statistics. J Arak Univ Med Sci, 11(2), 85-93.

[34] Moorey, S., Cort, E., Kapari, M., Monroe, B., Hansford, P., Mannix, K., ... Hotopf, M. (2009). A cluster randomized controlled trial of cognitive behaviour therapy for common mental disorders in patients with advanced cancer. Psychological medicine, 39(5), 713-723.

[35] Moss, E. L., \& Dobson, K. S. (2006). Psychology, spirituality, and end-of-life care: an ethical integration? Canadian Psychology/Psychologie canadienne, 47(4), 284.

[36] Naderi, F., \& Kh, R. (2012). Relationship of spiritual intelligence and social intelligence with death anxiety in old women. J Women and Culture, 2(6), 5567.

[37] Newton, A. T., \& McIntosh, D. N. (2010). Specific religious beliefs in a cognitive appraisal model of stress and coping. International Journal for the Psychology of Religion, 20(1), 39-58.

[38] Paloutzian, R. F., \& Park, C. L. (2014). Handbook of the psychology of religion and spirituality: Guilford Publications.

[39] Peach, H. G. (2003). Religion, spirituality and health: how should Australia's medical professionals respond? Medical journal of Australia, 178(2), 86-88.

[40] Petro-Nustas, W. (2002). Health-related behaviors and lifestyle factors of patients with breast cancer. Cancer nursing, 25(3), 219-229.

[41] Redd, W. H., \& Andrykowski, M. A. (1982). Behavioral intervention in cancer treatment: controlling aversion reactions to chemotherapy. Journal of consulting and clinical psychology, 50(6), 1018.

[42] Richards, P. S., Hardman, R. K., \& Berrett, M. E. (2007). Spiritual approaches in the treatment of women with eating disorders: American Psychological Association.

[43] Riley, B. B., Perna, R., Tate, D. G., Forchheimer, M., Anderson, C., \& Luera, G. (1998). Types of spiritual well-being among persons with chronic illness: Their relation to various forms of quality of life. Archives of physical medicine and rehabilitation, 79(3), 258-264. 
[44] Seligman, M. E. (1974). Depression and learned helplessness: John Wiley \& Sons.

[45] Seyedfatemi, N., Borimnejad, L., Hamooleh, M. M., \& Tahmasebi, M. (2014). Iranian nurses' perceptions of palliative care for patients with cancer pain. International journal of palliative nursing, 20(2), 69-74.

[46] Shreve-Neiger, A. K., \& Edelstein, B. A. (2004). Religion and anxiety: A critical review of the literature. Clinical psychology review, 24(4), 379-397.

[47] Simoni, J. M., Martone, M. G., \& Kerwin, J. F. (2002). Spirituality and psychological adaptation among women with HIV/AIDS: Implications for counseling. Journal of Counseling Psychology, 49(2), 139.

[48] Sirus, M., \& Ebrahimi, A. (2009). Epidemiology of tumor in women's breast in Isfahan. Iranian J Surg, 16(3), 1-6.

[49] Taylor, S. E. (1983). Adjustment to threatening events: A theory of cognitive adaptation. American psychologist, 38(11), 1161.

[50] Tsevat, J. (2006). Spirituality/religion and quality of life in patients with HIV/AIDS. Journal of general internal medicine, 21(S5).

[51] Wachholtz, A. B., \& Pargament, K. I. (2005). Is spirituality a critical ingredient of meditation? Comparing the effects of spiritual meditation, secular meditation, and relaxation on spiritual, psychological, cardiac, and pain outcomes. Journal of behavioral medicine, 28(4), 369-384.

[52] Yang, K.-P., \& Mao, X.-Y. (2007). A study of nurses' spiritual intelligence: A cross-sectional questionnaire survey. International journal of nursing studies, 44(6), 999-1010.

[53] Yavari, P., Mosavizadeh, M., Sadrol-Hefazi, B., \& Mehrabi, Y. (2005). Reproductive characteristics and the risk of breast cancer--a case-control study in Iran. Asian Pacific journal of cancer prevention: APJCP, 6(3), 370-375. 